\title{
Absorption of carbohydrate derived from rice in children aged 1-3 years
}

\author{
Agus Firmansyah, Daniel Effendi, Sri Rezeki H Hadinegoro, \\ Aswitha Boediarso, Badriul Hegar Syarif, Pramita Gayatri \\ Department of Child Health, Medical School, University of Indonesia, \\ Cipto Mangunkusumo Hospital, Jakarta
}

\begin{abstract}
Many studies shows that rice starch is well-absorbed in gastrointestinal tract, even better as a composition with electrolyte to overcome diarrhea. Although in small number, there is still a various prevalence of carbohydrate malabsorption, both with rice starch and with other starch. Khin-Maung-U found significant $(66.5 \%)$ prevalence of rice starch in Burmese children malabsorption, whereas rice starch is readily obtained in countries with rice as the population staple food, so that ability to absorb rice starch in Indonesian children need to be studied. Breath hydrogen test (BHT) was performed in 86 Indonesian children aged 1-3 years on Pejaten Barat Subdistrict, Pasar Minggu, South Jakarta. Among the 86 children given meal test with rice starch cakes $80 \mathrm{~g}$ for each children, 82 children (95.3\%) can absorb rice starch well, but 4 children (4.7\%) suffered from rice starch malabsorption. Currently it is unknown certainly the type of the malabsorption. Previous researchers found that rice malabsorption is due to enzyme deficiency and intestinal motility disturbance. In this study there were 16 children (18.6\%) coming from social-economically underprivileged family, most of the mothers with junior high school and lower educational level, and the majority of parent occupation were on private and labor sectors. There was no significant relation $(p>0.05)$ between diarrhea effects on rice starch malabsorption in 6 children $(7 \%)$, history of low birth weight baby $(15.1 \%)$, undernourished or malnutrition status in 35 children (40.7\%), and worm and/or fungal infection in 17 children (19.8\%). [Paediatr Indones 2001; 41:132-140]
\end{abstract}

Keywords: carbohydrate absortion, breath hydrogen test, children, infection

\begin{abstract}
STARCH IN RICE IS THE MOST IMPORTANT AND THE greatest number of carbohydrate source which is cheap and easy to get. ${ }^{1.4}$ In Indonesia, rice is the staple food and the source of energy and protein, $58 \%$ and $50 \% .{ }^{2}$ Nowadays, the number of poor family in Indonesia is almost 17.5 million (39.78\%). ${ }^{5}$ According to SKRT 1995, the number of children under 5 years with malnutrition is $28.6 \%$ and $8.1 \%$ of them is severe. 6 Since monetary crisis in 1997, more than 4 million children under 5 years suffer from malnutrition. ${ }^{5}$ Considering that the pattern of food
\end{abstract}

Correspondence: Agus Firmansyah, M.D., PhD. Department of Child Health, Medical School, University of Indonesia, Jalan Salemba 6, Jakarta 19430, Indonesia. Tel. 62-213907742; Fax. 62-21-3907743 consuming on 1-3 year-old child still depend on what is available (passive consumer), meanwhile physical growth is less than in infant period. They have more activities, those fact, make children in this period is more vulnerable to get infection and malnutrition. ${ }^{\text {? }}$ Factors which can cause carbohydrate malabsorption in 1-3 year old children are LBW history, malnutrition, diarrhea, infection, worm's parasite infection, low family social economic, and mother's education history, etc. ${ }^{8-}$ ${ }^{10}$ Levitt $^{11}$ observed many kinds of carbohydrate in healthy people and apparently, it's only rice and wheat flour-gluten free which is completely absorbed where as others cereals nutrient have partial malabsorption. Starch in rice is one of important nutrients in management of children with malnutrition. KhinMaung- $\mathrm{U}^{12}$ et al, in Burma (1988), on carbohydrate absorption research with BHT, found that 133 children under 5 year old $(66,5 \%)$ had malabsorption in 200 
children under 5 observed. It might have no association with malnutrition state but the state is often result from gastrointestinal tract and respiratory tract infection and also decrease of intake. Firmansyah ${ }^{13}$ observed starch from maizena, wheat, rice, manihot, sago absorption in white mouse and found that white mouse gut mucous could digest and absorb those starch well. So far, nobody has ever done any research about carbohydrate absorption that comes from rice in 1-3 year old children in Indonesia. The purpose of this research is to get basic data about carbohydrate absorption on 1-3 year old children in Department of Child Health, Medical School, University of Indonesia, Jakarta.

\section{Methods}

This was a prospective, cross-sectional study aimed to find out the prevalence of carbohhydrate derived from rice malabsorption. The study was carried out on Pejaten Barat Subdistrict, Pasar Minggu, South Jakarta and on Department of Child Health, Medical School, University of Indonesia, extending from December 1998 to July 1999. Accessible population was children aged 1-3 years visiting integrated health post (Posyandu) on Pejaten Barat Subdistrict, Pasar Minggu, South Jakarta. Exclusion criteria were respiratory disorder, history of gastrointestinal surgery and refuse to participate in the study.

The study was done by recording all necessary subject data into a special form, physical examination and nutritional status of each child was determined using weight for age criteria as recommended by Workshop on Nutritional Anthropometry in 1975, issued by the Ministry of Health which is the Harvard standard modification by using growth chart named KMS.9,14 Body weight was measured using a Dacin weight scale as usually utilized at integrated health post with an accuracy of $0.1 \mathrm{~kg}$ and issued by the Ministry of Health. Body weight value on the uppermost growth line on growth chart is $100 \%$ to Harvard median $(50 \%$ Harvard), and dotted line is $80 \%$ to Harvard median. Well-nourished between dotted line till the uppermost growth line on KMS (80\%) and below this dotted line was undernourished or malnourished.

Effect of nutritional status on malabsorption is undernutrition or malnutrition on gastrointestinal tract that may cause maldigestion and malabsorption. The more severe degree of malnutrition that may cause more severe malabsorption. ${ }^{15}$ Variables that were used in the study included undernutrition and well-nourished states. Diarrhea was define as increased frequency of defecation, change of stool consistency to be looser or increased stool volume than usual. The change of stool consistency is usually more important than the stool volume itself. ${ }^{16}$

Variable used in diarrhea episode in the study was when diarrhea frequency was more than 3 times a day with liquid consistency. Duration and frequency of diarrhea occurrence influenced nutritional state and gastrointestinal tract function. ${ }^{17}$ Diarrhea frequency was diarrhea occurrence at least once a month over 3 months consecutively or diarrhea occurred for more than 7 days. Subjects of the study were divided into two group; group with frequent diarrhea and group of infrequent diarrhea. Feeding pattern: Food supplement administered too early and inappropriately might result in maldigestion and malabsorption. ${ }^{18}$ Variable used in the study was breast feeding/formula pattern and age of solid food introduction.

On breast feeding pattern, the subjects were divided into 2 groups namely group with exclusive breast feeding for 4 months or more and group with breast feeding and formula for $<4$ months. Introduction of solid food was assessed based on age the first time the subject received solid food. Subjects were divided into 2 groups; those who received solid food before 4 months old and those who received solid food after 4 months old. History of parasitic/fungal infection: on the basic of macroscopic and microscopic stool laboratory examination. If there was a possibility of malabsorption, examination was continued with stool analysis.

Based on the results, two groups were found, group with positive and negative parasitic/fungal infection. History of low birth weight baby; assessed on the basic of subject's birth weight. Based on history of low birth weight baby, birth weight was divided into birth weight $<2500$ grams (LBW) and birth weight ${ }^{3}$ 2500 grams. ${ }^{9,19}$ Family income level was assessed by calculating family income total (father, mother, and other member) divided then by family burden number. On the basic of national level was income per capita for Indonesia 1999 that is Rp. 42,500/month for limit of poor population, criteria determined was as follows; unwealthy per capita $<$ Rp. 42,500/month and wealthy $>$ Rp. 42,500/month. Respiratory disorder or disturbance was acute asthmatic attack, whereas the 
history of digestive tract surgeries included history of colostomy or laparotomy, on Morbus hirschprüng case, anal atresia, anthral web, intestinal malrotation, gut shortening surgery, etc.

BHT was done on each subject using meal test, at 0 minute namely upon consuming rice starch after fasting for 5 hours, then every 30 minutes for 4 hours. Respiratory hydrogen was measured with practical 4 digits BHT portable LCD, Hoes Loos Lactometer version $1.0 \mathrm{CvO}$-HMLT (made from England). The basic principle for hydrogen measurement was detection with electrochemical censor specific to $\mathrm{H} 2$ gas. $\mathrm{H} 2$ is bound by negative electrode through reaction equation: $\mathrm{H} 2$ $=2 \mathrm{H}++2 \mathrm{e}$ and oxygen $(\mathrm{O} 2)$ was bound by positive electrode through reaction equation: $1 / 2 \mathrm{O}_{2}+\mathrm{H}++$ $2 \mathrm{e}=2 \mathrm{H}_{2} \mathrm{O}$. BHT calibration was performed using free air (200 ppm H2) as null value. Measurement range of H2 was 1-1999 ppm, with selectivity $<10 \%$ due to interference by carbonmonoxide gas $(\mathrm{CO})$. Respiratory hydrogen was caught and transmitted to electrode through T-piece system installed on mouth and/ or nose of the subject, for about 10-30 seconds or till condensation appear on mask, as to there was no expiratory air escape and subject was still able to breath through valve of T-piece. Results were seen directly on LCD.

Starch mean in the study was rice starch. Into the starch cool boiled water was added so that the volume reached 5-10 times (10-20\% solution). To make sweet taste and as flavor Tropicana Slim syrup (low calorie and sugar free) was added then boiled for 15 30 minutes until gelatinization process took place. Rice starch malabsorption is a absorption disorder of rice starch due to hydrolitic phase inhibition of all glycosidic bonds. Undigested rice starch continued to fill in the intestinal lumen and was metabolized by bacteria into carbondioxide, hydrogen, other gases and inorganic acids as to make bloating, frequent flatulence and diarrhea. ${ }^{21-23}$ Malabsorption was considered positive if BHT result ${ }^{3} 20$ ppm or $<20$ ppm followed by clinical symptoms at the time of measurement such as diarrhea, abdominal pain, bloating, vomiting, flatulence, and BHT considered negative if the result $<20 \mathrm{ppm}$.

\section{Results}

\section{A. Demography}

Population number of study location (RW 6 and 8) was 9520 consisting of 5123 males and 4397 females.
The number of population aged 0-4 years in Pejaten Barat Subdistrict was 3209 comprised 1984 boys and 1225 girls. Live hood of most RW 8 population was tailor business. Residential environment in Pejaten Barat along Pejaten Barat street was living area for middle to upper class population, whereas most of the remaining area inhabited by those coming from middle to lower class. Aged 1-3 years children registered in integrated health post of Pejaten Barat Subdistrict was 100 children among 165 those who aged $0-4$ years. The residential environment was dense enough with house line separated by narrow path, plastered ditch and stream. Children were seen do defecation into ditch or stream.

\section{B. Subject characteristics}

\section{Parental Occupation}

Most of parent were salaried employee monthly in private company including security unit and driver, self-employee such as trader and tailor business namely 47 people $(54.7 \%)$. Follow by laborer, mostly laborer with daily/weekly salary, 31 people $(36 \%)$ and the remaining 8 people $(9.13 \%)$ were civil servant and irregular employee.

\section{Socio-economic Status}

The lowest income per capita Rp. 17,300 and highest Rp. 228,500/month. Respondent income per capita mean was Rp. 81,000/month with SD Rp. 46,000. Socio-economic state of unwealthy with low income per capita ( $<$ Rp. 42,500/month) 16 respondents (18.6\%) and wealthy (> Rp. 42,500/month) 70 respondents $(81.4 \%)$.

\section{Maternal age}

The youngest maternal age was 18 years old and the oldest was 40 years. Mean maternal age 26.5 years with SD 4.7 years.

\section{Maternal educational Level}

In the study, most of mothers had educational level of elementary school or not complete 53 people (61.6\%), junior high school level 21 people (24.4\%), and no mother with high education level. No one was illiterate. 


\section{History of low birth weight}

The lowest birth weight was 1800 grams, whereas low birth weight proportion was $15.1 \%$

\section{Children's age and sex}

The mean age of the subjects was 22.8 months with SD 7.8 months. The sex distribution were 33 boys (38.4\%) out of 86 children.

\section{Nutritional status}

Undernourished and severe PEM (1 children) was found in 35 children (40.7\%), the remaining 51 children $(59.3 \%)$ were well nourished.

\section{History of feeding pattern}

Exclusive breast feeding 36 (42\%) from breast feeding $61(71 \%)$, and early solid food administration 38 (44.2\%) out of 86 children. In general, children were given bananas when they were 4 days old.

\section{History of diarrhea}

Diarrhea in children was grouped by occurrence frequency; frequent diarrhea in $6(7 \%)$, infrequent in 80 children (93\%).

\section{Result of stool examination}

The stool laboratory examination showed parasitic/ fungal infection in 17 children (19.8\%) by; Ascaris lumbricoides 13 (15.11\%), Trichiuris trichiura 3 (3.5\%), and by Candida albicans 1 (1.2\%).

\section{Results of $\mathrm{BHT}$}

In this study 82 children (95\%) can absorb rice starch well, but only 4 (4.7\%) of these children showed rice starch malabsorption. Factors influence rice starch malabsorption in the study probably were: Nutritional status, history of diarrhea, history of low birth weight and parasitic/fungal infection.

\section{Effects of nutritional status on rice starch malabsorption}

Among 35 undernourished and severe PEM children, none of them indicated starch malabsorption, 4 out of 51 well-nourished children showed starch malabsorption (Table 1). Statistically, there was no significant relation between nutritional status and starch malabsorption.
TABLE 1 THE RELATION BETWEEN NUTRITIONAL STATUS AND RICE STARCH MALABSORPTION

\begin{tabular}{llcl}
\hline \multirow{2}{*}{$\begin{array}{l}\text { Nutrirional } \\
\text { Status }\end{array}$} & \multicolumn{2}{l}{ Malabsorption } & \\
& Yes & No & Total \\
\hline Undernourished & 0 & 35 & 35 \\
Well-nourished & 4 & 47 & 51 \\
\hline Total & 4 & 82 & 86 \\
\hline
\end{tabular}

Fisher exact test $\quad x^{2}=1.38 ; d f=1 ; p=0.14$

\section{EFFECTS OF DIARRHEA HISTORY ON RICE STARCH MALABSORPTION}

Out of 6 children with frequent diarrhea none of them with starch malabsorption, but 4 out of 80 infrequent children demonstrated malabsorption (Table 2). Statistically, there was no significant relation between history of diarrhea and starch malabsorption.

TABLE 2 THE RELATION BETWEEN HISTORY OF DIARRHEA AND RICE STARCH MALABSORPTION

\begin{tabular}{llcl} 
Diarrhea & \multicolumn{3}{l}{ Malabsorption } \\
Status & Yes & No & Total \\
\hline Undernourished & 0 & 6 & 6 \\
Well-nourished & 4 & 76 & 80 \\
\hline Total & 4 & 82 & 86 \\
\hline
\end{tabular}

Fisher exact test $x^{2}=0.20 ; d f=1 ; p=1.00$

\section{Effect of LBW history on rice starch malabsoption}

None of 13 LBW history of children showed starch malabsorption, but 4 out of 73 non-LBW indicated starch malabsorption (Table 3). Statistically, there was no significant relation between LBW and rice starch malabsorption.

\section{Effects of parasitic/fungal infection on rice starch malabsorption}

None of 17 children with parasitic/fungal infection showed rice starch malabsorption, but 4 out of 69 children without parasitic/fungal infection demonstrated malabsorption Table 4). Statistically, 
there was no significant relation between parasitic/ fungal and rice starch malabsorption.

TABLE 3. THE RELATION BETWEEN LBW HISTORY AND RICE STARCH MALABSORPTION

\begin{tabular}{llcl}
\hline LBW history & \multicolumn{3}{c}{ Malabsorption } \\
& Yes & No & Total \\
\hline Undernourished & 0 & 13 & 13 \\
Well-nourished & 4 & 69 & 73 \\
\hline Total & 4 & 82 & 86 \\
\hline
\end{tabular}

Fisher exact test $x^{2}=0.02 ; d f=1 ; p=1.0$

TABLE 4. THE RELATION BETWEEN PARASITIC/FUNGAL INFECTION AND RICE STARCH MALABSORPTION

\begin{tabular}{llcl} 
Parasiitic- & \multicolumn{3}{l}{ Malabsorption } \\
Fungal infection & Yes & No & Total \\
\hline Undernourished & 0 & 17 & 17 \\
Well-nourished & 4 & 65 & 69 \\
\hline Total & 4 & 82 & 86 \\
\hline
\end{tabular}

Fisher exact test $x^{2}=1.14 ; d f=1 ; p=0.58$

\section{Characteristics of 4 children with rice starch malabsorption}

Malabsorption in those 4 children consisted of 3 boys and 1 girl, Three children were 17-19 months old, 1 child was 35 months old. Educational level of mothers, 3 completed elementary school and 1 completed junior high school. Result of BHT positive between 90-210 minutes of observation. From 4 children, none of them had history of LBW, frequent diarrhea, undernutrition, or parasitic/fungal infection.

\section{Discussion}

\section{A. Demography and subject characteristics}

Population number of the study in RW 6 and 8 was $9,520(24 \%)$ consisting of 5,123 males (53.8\%) and 4,397 females (46.2\%), while the sexual distribution of studied subjects comprised 33 boys (38.4\%) and 53 girls (61.6\%). There was sexual distribution difference, namely there were more males $(53.8 \%)$ compared to females (46.2\%) in RW 6 and 8 otherwise there were less boys $(38.4 \%)$ than girls $(63.6 \%)$. Data from Pejaten Barat subdistrict shows that most parental occupation was civil servants, followed by trader/selfemployee and laborer. Whereas the occupation of this study were private workers, laborers, irregular employee and civil servants. This seems to be in contrast with the data from Pejaten Barat Subdistrict. It can be explained that due to Pejaten Barat subdistrict region generally was area with inhabitants of very wealthy class, different from those of study location in which many of them participate in integrated health post was unwealthy class.

Population characteristics of middle to lower class in subjects studied had mean middle to lower income (84.9\%), most of parental education level was elementary school $(61.6 \%)$, followed by junior high school (24.4\%), and senior high school only $14 \%$. According to Rasjid,24 the majority of occupation in urban poor area, consecutively, were trading sector, industry, services, and other sectors. Education of poor people was also low, in urban area about $89 \%$, whereas in this study was $61.6 \%$. Nutritional status of undernutrition in this study was high enough $(40.7 \%)$. History of feeding pattern did not find formula usage for $71 \%$ children, but $44.2 \%$ children received solid food earlier. Health service for most people was obtained from community health center and integrated health post. The population density in RW 6 and 8 was high without healthy environment causing high enough morbidity, seen on parasitic (worm) infection in this area was still high (18.6\%).

\section{B. Rice starch absorption broblem}

Studies on digestion of rice starch in human were carried out by Auricchio ${ }^{25}$ et al in 1968, using starch and glucose analysis method in stool. It was found that starch absorption in normal infants (4-7 months) and children (1-2 years) was highly efficient, the absorption coefficient was higher than 99\%. This conformed to results by other investigators that rice starch is best absorbed in comparison with other sorts of cerealia starch.26-28 and in form of mill rice starch is better absorbed. Whereas Khin-Maung- $\mathrm{U}$ et $\mathrm{al}^{12}$ in Burmese, in his study on rice starch absorption in 
children using BHT found prevalence of rice starch malabsorption for $66.5 \%$.

Out of 86 children aged 1 -3 years who were studied, 4 children $(4.7 \%)$ showed starch malabsorption, while Perman18 et al in 1984, found that starch malabsorption prevalence was less than 1\% among 230 healthy people. Even though malabsorption prevalence in this study was higher than Perman18 finding, but still lower compared to results by Khin-MaungU. ${ }^{12}$ Were intestinal flora kinds different? King and Toskes $^{30}$, found around $10-13 \%$ of intestinal flora did not produce $\mathrm{H} 2$ so might give false positive results, while according to study by Strocchi31 et al, $\mathrm{H} 2$ nonproducer were really rare. It seems that there are no difference intestinal flora types in malabsorption.

Factors affecting BHT, other than $\mathrm{H} 2$ non-producer intestinal flora presence, include starch type origin, starch treatment form, starch volume, activity and motility of intestinal, and history of antibiotic administration. ${ }^{30,32-34}$

Background of study subjects was the same as those of Khin-Maung- $\mathrm{U},{ }^{12}$ namely from middle to lower socio-economic class. The difference was KhinMaung-U12 investigation done in rural society, whereas this study was performed in suburban one, so that infection could be found prevalently. There were 107 (51\%) out of under five years children with undernutrition in Khin-Maung-U12 study, whereas in this study there $35(40.7 \%)$ out of 86 children with the same nutritional status. There is no significant difference was found between nutritional status and rice starch malabsorption. Kind of rice starch given was the same, but Khin-Maung- $\mathrm{U}^{12}$ made it into cooked rice form until $1 \frac{1}{2}$ times volume and the amount of administered was 3 grams $/ \mathrm{kg}$ bodyweight mixed with water or soup sauce. In Indonesian study what given was cake made from flour rice starch in the form of gel of 80 grams for each children aged 1-3 years. It seems that rice starch menu cause less malabsorption in this study compared to Khin-Maung ${ }^{12}$

Starch malabsorption in Khin-Maung-U12 investigation was finding caused by: ${ }^{12}$ (1) Presence of oligosacharidase and polysacharidase produced by bacteria such as acarbose resulting in competitive inhibition on mamalia intestinal alpha-glicosidase enzyme action; (2) suspection at subclinical overgrowth bacteria due intestinal destruction and malabsorption because of frequent infection exposure; (3) as a sec- ondary phenomenon of malnutrition. The cause of malabsorption in this study remains unclear.

\section{Factors affecting rice starch absorption}

\section{Nutritional status}

Malnutritional closely relates to chronic diarrhea and often associated with malabsorption due to pancreatic and brush border hypotrophy. This condition may cause the deficiency of digestive enzyme to metabolized nutrients in intestine, including glucoamylase enzyme.35 Unabsorbed carbohydrate then was fermented by bacterial overgrowth and undergo degradation into gases such as hydrogen. ${ }^{9,11}$ These formed gases cause clinical symptoms such as bloating, vomiting, flatulence, and diarrhea. Untreated, undernutrition gradually affect under five years children growth. ${ }^{36}$ Thus, detection of carbohydrate malabsorption can be done in undernourished children. There was no significant relation $(\mathrm{p}>0.05)$ between nutritional status and rice starch malabsorption (table 1). Children with undernutrition, in general are susceptible to infection. Acute diarrhea occur frequently in undernourished children. Many studies about the effect of rice starch administration on acute or chronic diarrhea showed beneficial useful in the treatment of diarrhea. Defecation frequency decreased, reduce fecal volume, recovery shortened, cheap, easily available, calories and protein present in starch that increase bodyweight. . $353-42^{\text {The }}$ prevalence of undernutrition in under five years children in this study (40.7\%) increased was higher than Household Health Survey (SKRT) 1995 along with the monetary crises that has been taking place since $1997 . .^{5,6}$

\section{History of Diarrhea}

Diarrhea, especially chronic diarrhea may cause malabsorption. ${ }^{35}$ The etiology of chronic diarrhea is still incompletely known. Though limited, acute diarrhea can result malabsorption by specific enteropathogen. ${ }^{35}$ Due to carbohydrate malabsorption, fermentation by bacteria overgrowth occurred in intestines and finally worsens diarrhea and bloating. It seems this study show that overgrowth bacteria have not been existed yet. This study show no significant relation $(\mathrm{p}>0.05)$ between diarrhea and rice starch malabsorption (table 2). 


\section{History of low birth weight}

The low birth weight outcome in the first five years of life manifest in neurologic disorder, growth retardation, mental retardation and learning difficulties. ${ }^{43}$ Physical growth retardation is influenced also by malabsorption in low birth weight on rice starch malabsorption. The prevalence of low birth weight in this study was $15.1 \%$, in accord with prevalence of low birth weight reported between $14-29 \%,{ }^{44}$ The current Indonesian prevalence of low birth weight is $8 \% .6$

\section{Parasitic/fungal infection}

Low socio-economic condition, low income, low parental educational and ignorancy on environmental health closely relate to worm infection. 45 This kind of infection is prevalent in children of under 10 years old, can cause recurrent abdominal pain, diarrhea, growth retardation, obstruction, nausea, anorexia and may other parasitic and enteropathogenic bacteria infection in combination. ${ }^{46}$ Complaints of recurrent abdominal pain, diarrhea and obstruction can be malabsorption symptoms. Therefore, it is important to know whether there is a relation between worm infection and malabsorption. Linklater ${ }^{47}$ et al, found that there was significant relation between rice starch malabsorption and Ascaris lumbricoides infection. Excess growth of Candida albicans, mainly in children under 3 years can result in carbohydrate malabsorption, inhibit water and electrolyte lead to diarrhea. ${ }^{3}$ This study, shows no malabsorption in 17 cases (100\%) infected with worm/fungal infection. All mothers were in junior high school-lower educational level. Prevalence of worm/fungal infection in this study was 17 out of 86 children (19.8\%). Rampen,45 in his study found the prevalence of worm infection in 46 of 76 subjects $(60 \%)$, whereas according to literature in some countries, prevalence of worm infection in low socio-economic area for all ages was about $80 \%$.

\section{Others}

Out of 4 children suffering from rice starch absorption, one of them has history of diarrhea, low birth weight, undernutrition or malnutrition and parasites/fungal infection. Rice starch absorption in those four children began to show positive result minutes 90-210 observation at the time of BHT examination. Three out of 4 children suffering from malabsorption were
17-19 months old. It is difficult to determine the cause of malabsorption in these 4 children because intestinal hydrogen concentration is under influence also of intestinal motility and children activities. Large samples are needed to determine the cause of the malabsorption.

Laboratory examination for fecal fat was positive for more than half of vision filed, followed by complex carbohydrate malabsorption such as starch, highly significant in demonstrating pancreatic insuficiency. 48 In this study fat malabsorption was not found. Parental educational factor was one of indirect causes of undernutrition/malnutirtion. ${ }^{15}$ The low level knowledge on nutrition of the parents result inadequate food intake and low socio-economic level is associated with low purchasing ability, influenced by low parental educational level affecting nutritional status and child morbidity.

\section{References}

1. Muchtadi D, Palupi NS, Astawan M. Metabolisme zat gizi: Sumber, fungsi dan kebutuhan bagi tubuh manusia. Jilid-I. Jakarta: Pustaka Sinar Harapan, 1993.

2. Winarno FG. Gizi dan makanan bagi bayi dan anak sapihan; pengadaan dan pengolahan. Jakarta: Pustaka Sinar Harapan, 1987.

3. Gaman PM, Sherrington KB (Alih bahasa: Kasmidjo RB), eds. Ilmu pangan: Pengantar ilmu pangan nutrisi dan mikrobiologi, 2nd edition. Yogyakarta: Universitas Gadjah Mada, 1992.

4. Hubeis M. Pengantar pengolahan tepung serealia dan bijibijian. Bogor: Institut Pertanian Bogor, 1984.

5. Hadi P. Kolom Kolegia: UNICEF: 4 juta lebih Balita Indonesia kurang gizi, dan BKKBN buka 'Crisis center'. Republika September 9, 1998; page 9.

6. Soemantri S, Budiarso RL, Suhardi, Sarimawar, Bachroen C, eds. Survei kesehatan rumah tangga (SKRT) 1995. Jakarta: Departemen Kesehatan RI, 1997.

7. Almatsier S. Penuntun diet anak; Rumah sakit Dr. Cipto Mangunkusumo dan Persatuan Ahli Gizi Indonesia, 2nd edition. Jakarta: Gramedia Pustaka Utama, 1992.

8. Sunoto. Maldigesti dan malabsorpsi pada MEP. In: Firmansyah A, Boediarso A, Suharyono, Sunoto, eds. Optimalisasi tatalaksana gagal tumbuh gastrointestinal guna meningkatkan kualitas sumber daya manusia. Naskah lengkap Pendidikan Kedokteran Berkelanjutan Ilmu Kesehatan Anak XXXI; Jakarta 4-5 Februari 1994. Jakarta: Balai Penerbit FKUI, 1994: 55-67.

9. Suharyono. Esensial gastroenterologi anak, 2nd edition. Jakarta: Balai penerbit FKUI, 1995. 
10. Sediaoetama AD. Ilmu gizi: untuk mahasiswa dan profesi di Indonesia. Jilid 2. Jakarta: Dian Rakyat, 1993.

11. Levitt MD. Production and excretion of hydrogen gas in man. N Engl J Med 1969;281: 122-7.

12. Khin-Maung-U, Bolin TD, Pereira SP, et al. Absorption of carbohydrate from rice in Burmese village children and adults. Am J Clin Nutr 1990; 52: 342-7.

13. Firmansyah A. Absorption of starch derived from cereals in malnourished rats. Diajukan pada; 8th Asian conference on diarrhoeal diseases; February, 26-28, 1997; Yogyakarta, 1997.

14. Samsudin. Penilaian keadaan gizi dan pertumbuhan: Cara, kegunaan, dan keterbatasan. In: Samsudin, Nasar SS, Sjarif DR, eds. Masalah gizi ganda dan tumbuh kembang anak. Naskah lengkap Pendidikan Kedokteran Berkelanjutan Ilmu Kesehatan Anak XXXV; Jakarta 11-12 Agustus 1995. Jakarta: Binarupa Aksara, 1995: 149-58.

15. Sunoto. Interaksi antara diare dan malnutrisi. In: Wulur $\mathrm{H}$, Firmansyah A, eds. Meningkatkan penanggulangan penyakit pencernaan guna meningkatkan kualitas hidup anak. Naskah lengkap Pertemuan Ilmiah Badan Koordinasi Gastroentrologi Anak Indonesia XI; Jakarta 29 Juni - 1 Juli 1989. Jakarta, 1989:241-50.

16. Suharyono. Terapi nutrisi pada diare kronik. In: Firmansyah A, Boediarso A, Suharyono, Sunoto, eds. Optimalisasi tatalaksana gagal tumbuh gastrointestinal guna meningkatkan kualitas sumber daya manusia. Naskah lengkap Pendidikan Kedokteran Berkelanjutan Ilmu Kesehatan Anak XXXI; Jakarta 4-5 Februari 1994. Jakarta: Balai Penerbit FKUI, 1994: 123-33.

17. Sunoto. Pendidikan medik pemberantasan diare: Buku ajar diare. Jakarta: Departemen Kesehatan RI, 1990.

18. Sunoto. Persistent diarrhea: Possible risk factors in Indonesia. Paediatr Indones 1993;33: 126-32.

19. Wahidiyat I, Matondang CS, Sastroasmoro S. Diagnosis fisis pada anak. Jakarta: FKUI, 1991.

20. Wawolumaya C. Survei epidemilogi sederhana bidang perilaku kedokteran/ kesehatan. Jakarta: Balai Penerbit FKUI, 1997.

21. Montgomery R, Conway TW, Spector AA. Gizi. In: Montgomery R, Conway TW, Spector AA (Alih bahasa: Staf Pengajar Biokimia, FKUI), eds. Biokimia berorientasi pada kasus-klinik, 5nd edition. Jakarta: Binarupa Aksara, 1993: 6-21.

22. Nasar SS, Sudibjo S. Gangguan gizi. In: Markum AH, Ismael S, Alatas H, Akib A, Firmansyah A, Sastroasmoro S, eds. Buku ajar ilmu kesehatan anak. Jilid 1. Jakarta: Bagian Ilmu Kesehatan Anak FKUI, 1991: 163-4.

23. Firmansyah A. Pengaruh malnutrisi terhadap saluran cerna tikus putih: perhatian khusus pada perkembangan morfologis, biokimiawi, dan fisiologis terutama kolon (Desertasi). Jakarta: Fakultas Kedokteran Universitas Indonesia, 1991.
24. Rasyid A. Identifikasi kemiskinan di Indonesia. In: Badan Urusan Logistik. Prosiding lokakarya peningkatan ketahanan pangan untuk menanggulangi kemiskinan; Jakarta 17 Juli 1993. Jakarta: Kantor Menteri Negara Urusan Pangan Republik Indonesia, 1993.

25. Auricchio S, Ciccimarra F, Rubino A, Prader A. Studies intestinal digestion of starch in man. Enzym Biol Clin 1968;9:321-37.

26. Levitt MD, Hirsh P, Fetzer CA, Sheahan M, Levine AS. H2 excretion after ingestion of complex carbohydrate. Gastroenterol 1984;92: 383-9.

27. Kerlin P, Wong L, Harris B, Capra S. Rice flour, breath hydrogen, and malabsorption. Gastroenterol 1984;87: 57885.

28. Kerlin P, Wong L. Breath hydrogen testing in bacterial overgrowth of the small intestine. Gastroenterol 1988;95: 982-8.

29. Perman JA, Modler SIV, Barr RG, Rosenthal P. Fasting breath hydrogen concentration: Normal values and clinical application. Gastroenterol 1984;87: 1358-63.

30. King CE, Toskes PP. Comparison of the 1-gram [14C]xylose, 10-gram lactulose-H2 and 80-gram glucose$\mathrm{H} 2$ breath tests in patients with small intestine bacterial overgrowth. Gastroenterol 1986;91:1447-51.

31. Strocchi A, Corzza G, Ellis CJ, Gasbarrini G, Levitt MD. Detection of malabsorption of low dose of carbohydrate: accuracy of various breath $\mathrm{H} 2$ criteria. Gastroenterol 1993; 105: 1404-10.

32. Colonna P, Leloup V, Buléon A. Limiting factors of starch hydrolysis. Eur J Clin Nutr 1992;46 (supl-2): S17-S32.

33. Englyst HN, Kingman SM, Cummings JH. Classification and measurement of nutritionally important starch fractions. Eur J Clin Nutr 1992;46 (Supl): S33-S50.

34. Olesen M, Rumessen JJ, Gudmand-Høyer E. Intestinal transport and fermentation of resistent starch evaluated by the hydrogen breath test. Eur J Clin Nutr 1994;48: 692-701.

35. Roy SK, Haider R, Akbar MS, Alam AN, Khatun M, Eeckel R. Persistent diarrhoea: clinical efficacy and nutrient absorption with a rice based diet. Arch Dis Child 1990;65: 294-7.

36. Kodyat BA. Masalah gizi masyarakat dan program penanggulangannya. In: Samsudin, Nasar SS, Sjarif DR, eds. Masalah gizi ganda dan tumbuh kembang anak. Naskah lengkap Pendidikan Kedokteran Berkelanjutan Ilmu Kesehatan Anak XXXV; Jakarta 11-12 Agustus 1995. Jakarta: Binarupa Aksara, 1995: 42-50.

37. Molla AA, Hossain M, Sarker SA, Molla A. Rice-powder electrolyte solution as oral therapy in diarrhoea due to Vibrio cholerae and Escherichia coli. The Lancet 1982;12: 1317-9.

38. Molla AM, Ahmed SM, Greenough III WB. Rice-based oral rehydration solution decreases the stool volume in acute diarrhoea. Bull WHO 1985;63(4): 751-6. 
39. Alam AN, Sarker SA, Molla AM, Rahaman MM, Greenough III WB. Hydrolysed wheat based oral rehydration solution for acute diarrhoea. Arch Dis Childhood 1987;62: 440-4.

40. Kenya PR, Odongo HW, Waswa K, et al. Cereal based oral rehydration solutions. Arch Dis Childhood 1989;64: 1032-5.

41. Patra FC, Mahalanabis D, Jalan KN, Sen A, Banerjee P. Is oral rice electrolyte solution superior to glucose electrolyte solution in infantile diarrhoea? Arch Dis Childhood 1982;57: 910-2.

42. Mohan M, Sethi JS, Daral TS, Sharma M, Bhargava SK, Sachdev HPS. Controlled trial of rice powder and glucose rehydration solutions as oral therapy for acute dehydrating diarrhea in infants. J Pediatr Gastroenterol Nutr 1986;5: 423-7

43. Behrman RE. The high risk infant. In: Behrman RE, Kliegman RM, Nelson WE, eds. Nelson textbook of pediatrics, 14th edition. Philadelphia: Saunders, 1992: 439-51.
44. KadriN. Prematuritas: Keberadaannya, tantangandan kesempatan tumbuh kembang mencapai sumber daya manusia yang handal. Pidatopengukuhan sebagaiguru besar tetap dalam Ilmu Kesehatan Anak-PerinatologiUniversitasIndonesia,Jakarta 17Maret 1999

45. Rampen ASL. Pencemaran tanah dengan telur Ascaris lumbricoides di Bale Kambang dan Cawang, Jakarta dengan penduduk yang berbeda keadaan sosial ekonomi (desertasi). Jakarta: Fakultas Pasca Sarjana Magister Sains Parasitologi. Fakultas Kedokteran Universitas Indonesia, 1986.

46. Pearson RD. Parasitic disease: Helminths. In: Yamada T, ed. Textbook of gastroenterology, 2nd edition. Philadelphia: JB Lippincott company, 1995: 2362-79.

47. Linklater JM, Khin-Maung-U, Bolin TD, et al. Absorption of carbohydrate from rice in Ascaris lumbricoides infected Burmese village children (abstract). J Trop Pediatr 1991; 38:323-6.

48. Ladas SD, Giorgiotis K, Raptis SA. Complex carbohydrate malabsorption in exocrine pancreatic insuffisiency. Gut 1993; 34: 984-7. 